\title{
Comparative Analysis of FDI Determinants in Russia and Brics Countries
}

\author{
Kotenkova S. N. ${ }^{a}$ \\ Davletshin E. A. ${ }^{b}$ \\ Volkova N. V.c \\ abc Kazan Federal University, Institute of Management, Economics and Finance, Kazan, 420008, Russia
}

\section{Doi:10.5901/mjss.2015.v6n1s3p304}

\begin{abstract}
In recent years changes in direction of foreign direct investments (FDI) started to attract more attention of economists. In this paper different economic indicators and variables as a factor of FDI growth are investigated. In the first part weregiven different classifications of FDI determinants. The second part was based on quantitative analysis of FDI determinants in BRICS countries. Data for analysis was provided by World Bank database of economic statistics. The last part includes polynomial regression model for Russia's FDI inflows and their dependence on different variables.
\end{abstract}

Keywords: polynomial regression, foreign direct investments, FDI determinants, variables

\section{Introduction}

In recent years the correlation between foreign direct investments is being investigated in economic literature, especially after the crisis in 2008. Special attention is being attracted to an influence of FDI to GDP and key determinants of foreign direct investment flows.

This paper offers unique classification of determinants of FDI and their qualitative analysis based on BRICS countries - Russia, China, India and Brazil.

\section{Review of Literature}

In this section, we provide brief literature reviews which investigate the determinants of FDI inflows across various economies. The classical model for determinants of FDI begins from the earlier research work of Dunning $(1973,1981)$ which provide a comprehensive analysis based on ownership, location and the internationalization (OLI) paradigm [6]. The empirical studies based on aggregate econometric approach are made by Agarwal (1980), Schneider et al (1985). Later on Lucas (1993) examines the determinants of FDI inflows for select East and South Asian economies during 1960 to1987 by using a model based on a traditional derived-factor of a multiple product monopolist[1,9,11]. The study finds that FDI inflows are more elastic with respect to cost of capital than wages and also more elastic with respect to aggregate demand in exports than domestic demand. Garibaldi et al (2002) analyze the FDI and Portfolio investment flows to 26 transition economies in Eastern Europe including the former Soviet Union from 1990 to 1999 [7]. The regression estimation indicates that the FDI flows are well explained by standard economic fundamentals such as market size, fiscal deficit, inflation and exchange rate regime, risk analysis, economic reforms, trade openness, availability of natural resources, barriers to investments and bureaucracy. However, the portfolio flows are poorly explained by the fundamentals. The study of Nonnenberg and Mendonca (2004) finds that the factors such as the market size measured by GNP, growth rate of the product, the availability of skilled labor, the receptivity of foreign capital, the country risk rating and stock market behavior seem to be the important determinants of FDI flows for developing countries comprising of 33 countries from 1975 through 2000[10].

\section{Classification of FDI Determinants}

Different sources offer different classifications of FDI determinants. Summarizing them we could segregate five major groups of factors of attracting FDI into economy:

1. Economic factors: market size, cost of primary factors of production, quality of primary factors of production, 
GNP;

2. Infrastructure: transport services, communications, financial institutes;

3. Economic policy;

4. Ease of doing business;

5. Geographical characteristics of market.

Among different international classifications the most interesting one is the United Nations Conference on Trade and Development (UNCTAD) index of investment potential. Since 2002 UNCTAD is publishing a yearly report of world investments where the investment attractiveness of countries-recipients of FDI is being described. UNCTAD segregate four basic factors of investment attractiveness for a region or a country:

1. Market;

2. Cost and quality of labor force;

3. Natural resources;

4. Infrastructure development.

These are the main groups of FDI determinants. Every one of them includes more specific factors:

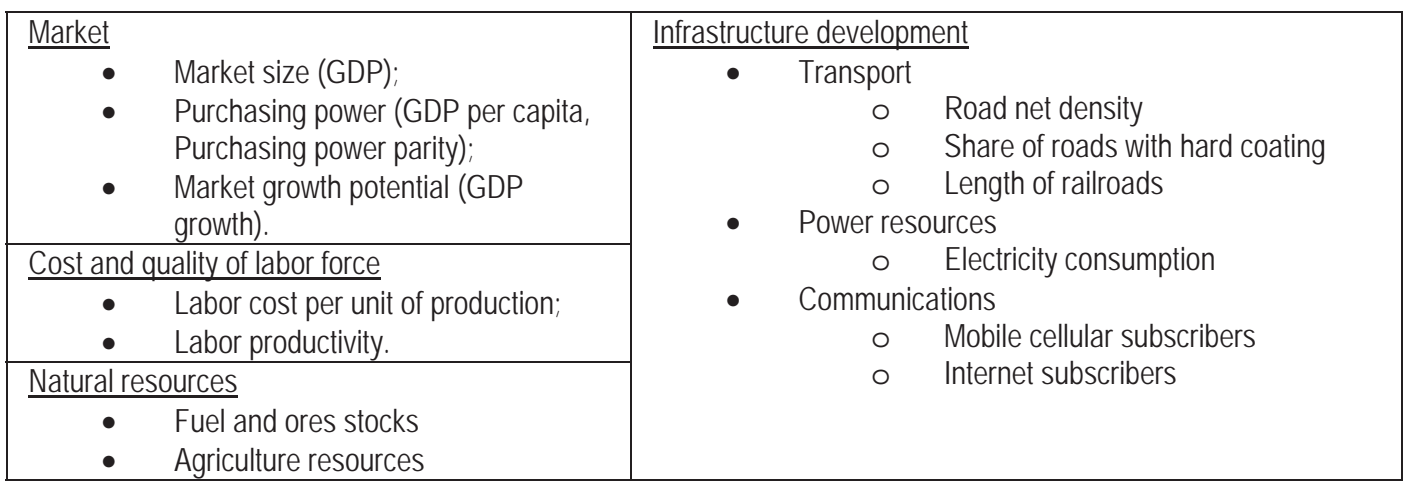

Every investor finds the most profitable combination of four main determinants and chooses the most advantageous region for investments.

All these factors have a significant impact on FDI flows but this classification does not embrace the whole specter of FDI factors. To see the whole picture, we should look at them from a position of investor. The basis of every investment project is a combination of three major parameters: reward, risk and liquidity. Obviously, the best scenario should be based on high profitability and reward, high liquidity and low risk. Some sources in addition to risk and reward take time. But from the investor's point of view this is not correct, because time itself is one of the determinants of profitability. Thus, every factor determining FDI inflows to the economy one way or another has influence on one of three major parameters. According to this we offer different investor-orientated classification (Table 1.)

Table 1. FDI determinants.

\begin{tabular}{|c|c|c|c|c|}
\hline & Group of factors & Determinant & Variable & Source \\
\hline \multirow{12}{*}{ Profitability } & \multirow{3}{*}{ Market capacity } & GDP value & US\$ & \multirow{5}{*}{ WorldDevelopmentIndicators. World Bank Database } \\
\hline & & Growth potential & GDP dynamics, \% & \\
\hline & & Effective demand & Average wage, US\$ & \\
\hline & \multirow{3}{*}{ |Labor potential } & Labor force & Number of people & \\
\hline & & Labor productivity & $\begin{array}{l}\text { Share of GDP per person } \\
\text { employed }\end{array}$ & \\
\hline & & Education & Index, rating & $\begin{array}{l}\text { InternationalHumanDevelopmentIndicators. } \\
\text { Educationindex }\end{array}$ \\
\hline & \multirow{3}{*}{$\begin{array}{l}\text { Infrastructure } \\
\text { potential }\end{array}$} & Transport services & $\begin{array}{l}\text { Goods transported (million } \\
\text { ton/km) }\end{array}$ & \multirow{3}{*}{ WorldDevelopmentIndicators. WorldBankDatabase } \\
\hline & & Power sources & Electricity production & \\
\hline & & Communication & $\begin{array}{l}\text { Mobile cellular subscription per } \\
100 \text { people }\end{array}$ & \\
\hline & \multirow{3}{*}{ Financial potential } & Taxes & $\begin{array}{l}\text { Total tax rate, \% of commercial } \\
\text { profits }\end{array}$ & \multirow[t]{2}{*}{ WorldDevelopmentIndicators. World Bank Database } \\
\hline & & Cost of capital & Discount rate, $\%$ & \\
\hline & & Cost of starting a business & $\%$ of income per capita & Doing business \\
\hline
\end{tabular}




\begin{tabular}{|c|c|c|c|c|}
\hline \multirow{5}{*}{ Risk } & Government policy & $\begin{array}{l}\text { Strength of investor } \\
\text { protection }\end{array}$ & Index (1-10) & \multirow{4}{*}{ Doing business } \\
\hline & \multirow{3}{*}{$\begin{array}{l}\text { Administrative } \\
\text { factors }\end{array}$} & Registration of business & Time in days & \\
\hline & & Registration of property & Time in days & \\
\hline & & $\begin{array}{l}\text { Dealing with construction } \\
\text { permits }\end{array}$ & Time in days & \\
\hline & Political factors & Rating of political instability & Index, rating & Failed State Index \\
\hline \multirow{2}{*}{ Liquidity } & Stock markets & Capitalization & Billion US\$ & WorldDevelopmentIndicators. WorldBankDatabase \\
\hline & Closing a business & Recovery rate & Cents per dollar & Doing business \\
\hline
\end{tabular}

Apparently, this classification also cannot be universal. The main limitation for this classification was the ability to analyze all of the factors quantitatively, so only those factors which could be calculated were added to the model.

\section{Analysis of FDI Determinants}

Statistical data for the analysis was provided by open sources such as World Bank database, "doing business" reports, ratings and government's statistical databases. The analysis was based on four BRIC countries - Russia, Brazil, China and India for the period between 2007 and 2012.

All the factors of FDI inflows which could be calculated were put in unified database. At the first stage the correlation between the share of world FDI inflows of every country and each determinant for the whole period. Results of these calculations shows that set of FDI determinants cannot be unified for each country.

For example, the best match with chosen determinants has China. Most of the factors have a very strong correlation (over 0.9) with FDI inflows. In the meantime India has almost no correlation at all.

For Russia, the most important determinants appeared to be:

- GDP value

- Average wage

- Labor force

- Electricity production

\section{Model Specification}

At the first stage as model of evaluation of determinants of FDI inflows in Russia was offered a linear regression model with four variables from the above. It was assumed that these variables could allow figuring the degree of influence of each one of them to the dependent variable - the share of Russia in FDI world inflows. However, initial results have showed their low significance and low values of t-statistics despite the high coefficient of determination. This fact could be explained by multicollinearity between the independent parameters of regression. Evaluation of correlation coefficients between variables shows their strong linear dependence, so they cannot be used in an adequate model.

Table 2. Pair correlation of variables

\begin{tabular}{|l|c|c|c|c|c|}
\hline & $\begin{array}{c}\text { GDP (trillion } \\
\text { US\$) }\end{array}$ & $\begin{array}{c}\text { Labor force } \\
\text { (million people) }\end{array}$ & $\begin{array}{c}\text { Average wage } \\
\text { (hundreds US\$) }\end{array}$ & $\begin{array}{c}\text { Electricity production } \\
\text { (trillion kWh) }\end{array}$ & $\begin{array}{c}\text { FDI (\% of world } \\
\text { inflows) }\end{array}$ \\
\hline GDP (trillion US\$) & 1 & & & & 0,93 \\
\hline Labor force (million people) & 0,79 & 1 & & & 0,80 \\
\hline Average wage (hundreds US\$) & 0,99 & 0,74 & 1 & 1 & 0,92 \\
\hline Electricity production (trillion kWh) & 0,96 & 0,91 & 0,93 & 1 & 0,92 \\
\hline
\end{tabular}

As the parametersdegree of influence on dependent variable cannot be adequately calculated, it was decided to build four different non-linear polynomial regression models. To measure the degree of influence of independent variable on the result the K. Pearson correlation ratio for non-linear regressions was calculated. The formula for this ratio is given below:

$$
\mathrm{r}=\sqrt{\frac{\sigma_{y}^{2}-\sigma_{y x}^{2}}{\sigma_{y}^{2}}}
$$

For every regression equation coefficients of determinations and t-statistics were calculated as well.

1. Relationship between FDI in Russia in \% of world FDI inflows and GDP values. 
$Y=-0.0084604 x^{2}+0.0352237 x-0.003909$, where

$Y$ - Russia's FDI share of world FDI inflows in \%.

$x-$ GDP value in trillion US\$.

$\mathrm{R}^{2}=0.91 ;$ t-statistic $-42.85 ; \mathrm{r}=0.96$.

2. Relationship between FDI in Russia in \% of world FDI inflows and average wage in hundreds US\$.

$Y=-0.00045 x^{2}+0.00802 x-0,00251$, where

$Y$ - Russia's FDI share of world FDI inflows in \%.

$\mathrm{X}$ - Average salary in hundreds US\$.

$\mathrm{R}^{2}=0.89$; t-statistics $-36.35, \mathrm{r}=0.94$.

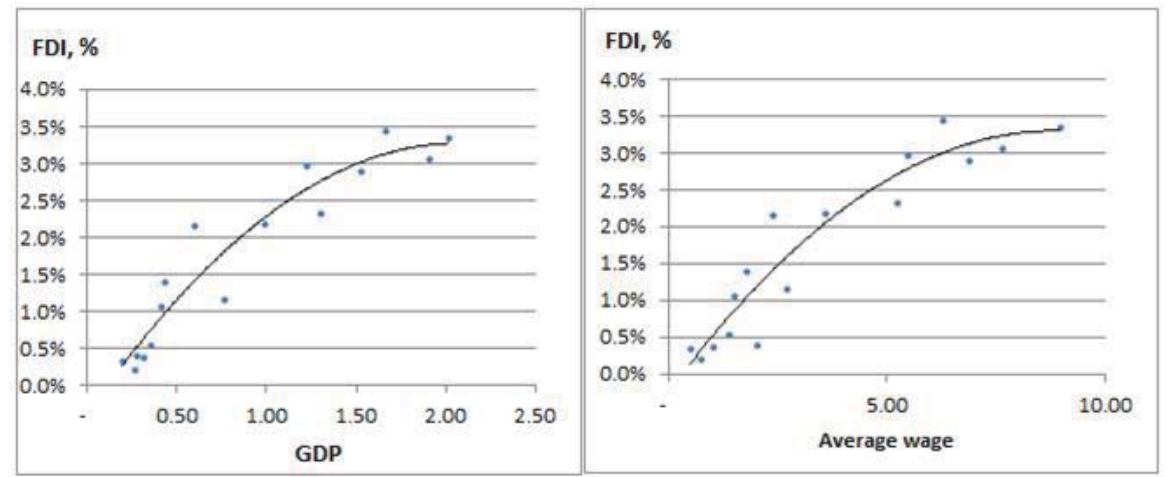

Figure 1. Scatter diagrams of relationship between Russia's share of FDI world inflows and GDP value (left side);

Average wage (right side)

3. Relationship between FDI in Russia in \% of world FDI inflows and labor force in million people.

$Y=-0.0007 x^{2}-0.1054 x+3.7151$, where

$\mathrm{Y}$ - Russia's FDI share of world FDI inflows in \%.

$\mathrm{X}$ - Labor force in millions people.

$\mathrm{R}^{2}=0.90$; t-statistics $-38.01, \mathrm{r}=0.95$.

4. Relationship between FDI in Russia in \% of world FDI inflows and electricity production in trillion $\mathrm{kWh}$.

$Y=-4.9994 x^{3}+14.425 x^{2}-13.686 x+4.2859$, where

$Y$ - Russia's FDI share of world FDI inflows in \%.

$\mathrm{X}$ - Electricity production in trillion $\mathrm{kWh}$.

$\mathrm{R}^{2}=0.88$; t-statistics $-30.8, \mathrm{r}=0.94$.
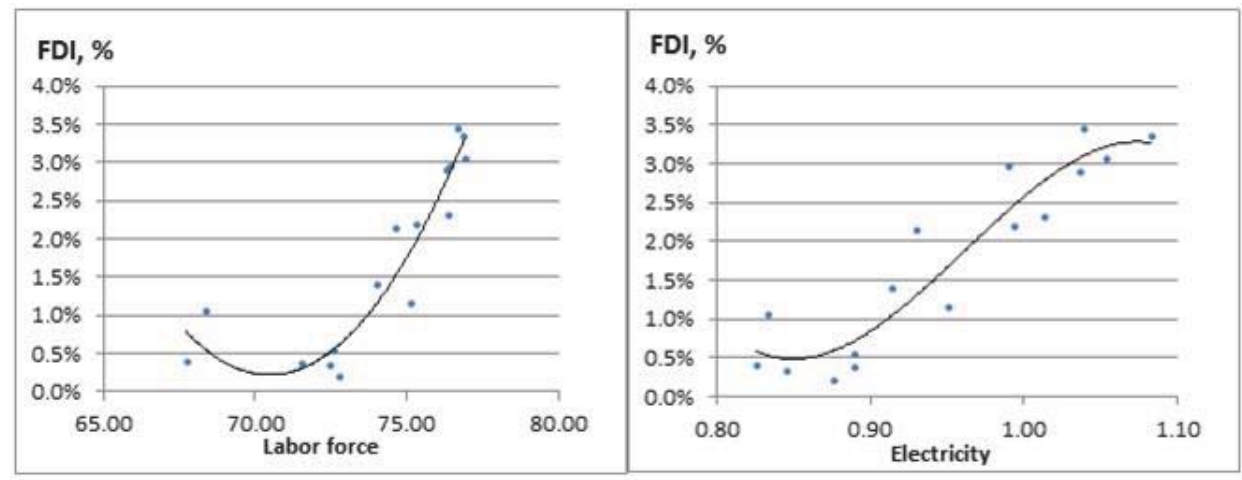

Figure 2. Scatter diagrams of relationship between Russia's share of FDI world inflows and Labor force (left side); Electricity production (right side)

Thus, these regression models show strong Russia's FDI share of world inflows on independent variables. According to the values of R2 and $r$, highest dependence of the FDI inflows can be seen on the labor force and GDP values. 


\section{Initial Results and Conclusion}

The initial results of analysis show that indeed there are many methods and classifications to describe investment climate and potential of the particular region. There is no unified classification for every country even among developing ones. Most of developing countries could be characterized by very high correlation between their FDI inflows and major economic and investment climate indicators such as average wage, tax rates and "doing business" indicators. There are many ways to make FDI inflows consistently grow by managing these parameters.

\section{References}

Agarwal, J.P. (1980) 'Determinants of foreign direct investment: a survey', WeltwirtschaftlichesArchiv, No.116, pp. 739-77.

Gibadullin, M.Z., Fazlieva, E.P., Nurieva, A.R., Grigoryeva, L.L. Territorial aspects of migration processes in Russia. Mediterranean Journal of Social Sciences, Volume 5, Issue 12, June 2014, Pages 93-96.

Asiedu, E. (2002) 'On the determinants of foreign direct investment developing counties: is Africa different?,' World Development, Vol. 30 (1), pp.107-119.

Asterious, D. (2006) 'Applied econometrics: a modern approach using Eviews and Microfit', Palgrave Macmillan, pp: 369- 378.

Dunning, J.H. (1973) 'The determinants of international production', Oxford Economic Papers, Vol. 25.

Garibaldi, P., Mora. N., Sahay. R. and Zettelmeyer. J. (2002) 'What moves capital to transition economies?', IMF working paper WP/02/64.

Hausman, J. A. (1978) 'Specification tests in econometrics', Econometrica, Vol. 46, pp1251- 71.

Lucas, R.E. (1993) 'On the determinants direct foreign investment: evidence from East and South East Asia', World Development, Vol. 21(3), pp 391- 406.

Glebova, I., Khabibrakhmanova, R., Yasnitskaya, Y. The analysis of the impact of the investment attractiveness factors of the region on the fixed capital investments in the economy of the Republic of Tatarstan // Middle East Journal of Scientific Research 17 (10), pp. 1498-1502,-2014.

Gallyamova D. Kh. Development of Globalization in the Modern Economy // World Applied Sciences Journal 30 (9): 1160-1165, 2014

Nurieva, A.R., Gibadullin, M.Z., Fazlieva, E.P. Stability of interregional trade and economic relations as the factor of competitiveness of territories, World Applied Sciences Journal, Volume 29, Issue 4, 2014, Pages 501-505

Nonnenberg and Mendonça. (2004) 'The determinants of direct foreign investment in developing countries', IPEA Working paper.

Glebova I.S., Yasnitskaya Ya.S., Maklakova N.V. Possibilities of "Smart City" Concept Implementing: Russia' s Cities Practice/l Mediterranean Journal of Social Sciences.- Vol.5, No12, (2014)-pp.129 - 133.

Schneider, Friedrich and Frey, B.S. (1985) 'Economic and Political Determinants of Foreign Direct Investment', World Development, Vol 13(2).

Lensink, R. and Morrissey, O. "Foreign Direct Investment: Flows, Volatility and Growth in Developing Countries", 2001. University of Nottingham.

Bayraktar, N. (2013), "Foreign direct investments and investment climate". "International Conference on Applied Economics (ICOAE) 2013", Procedia Economics and Finance 